\title{
Factors influencing the structure and spatial distribution of fishes in the headwater streams of the Jaú River in the Brazilian Amazon
}

\author{
Kemenes, $A .^{a, b *}$ and Forsberg, BR. ${ }^{b}$ \\ ${ }^{a}$ Empresa Brasileira de Pesquisa Agropecuária (Embrapa Meio-Norte), Av. Duque de Caxias, 5650, CEP 64006-220, \\ Teresina, PI, Brazil \\ ${ }^{\mathrm{b}}$ Coordenação de Pesquisas em Ecologia - CPEC, Instituto Nacional de Pesquisas da Amazônia - INPA, Av. André Araújo, \\ 2936, Petrópolis, CEP 69067-375, Manaus, AM, Brazil \\ *e-mail: alexandre.kemenes@embrapa.br
}

Received: September 13, 2012 - Accepted: May 23, 2013 - Distributed: November 30, 2014

(With 4 figures)

\begin{abstract}
The aim of this study was to investigate the influence of spatial variation in river channels and habitats on the distribution of fish communities in the headwater streams of the Jaú River System, a blackwater tributary of the Negro River. Collections and measurements were made in 34 headwater streams during the period of November- December, 1998. Fish were captured with fish traps and hand nets along standard reaches of two meanders. Data on benthic habitat structure, stream depth and width were collected along lateral transects in each sample reach. A total of 66 fish species from 24 families were collected and classified into seven trophic guilds: allocthonous insectivore, autochthonous insectivore, general insectivore, piscivore, detritivorous planktivore, detritivorous insectivore and insectivorous piscivore. Variations in the distribution and diversity of bottom substrates were important factors influencing fish community structures in these systems. Also, variation in stream size explained the observed variability in fish communities.
\end{abstract}

Keywords: Central Amazon, fish community, trophic guilds.

\section{Fatores influenciando a estrutura e distribuição espacial dos peixes nos Igarapés de cabeceira do Parque Nacional do Jaú, Amazônia Central}

\begin{abstract}
Resumo
O objetivo desse estudo foi investigar a influência da variação espacial de características físicas do canal dos igarapés e habitats na distribuição das comunidades de peixes em igarapés de cabeceira no sistema do rio Jaú. O rio Jaú é um tributário de águas pretas do rio Negro. Coletas e medidas foram realizadas em 34 igarapés de cabeceira durante os períodos de novembro a dezembro de 1998. Os peixes foram capturados com armadilhas e puçás ao longo de dois meandros em cada local. Um total de 66 espécies de peixes de 24 famílias foram coletados e classificados em sete guildas tróficas: insetívoro alóctone, insetívoro autóctone, insetívoro em geral, piscívoro, detritívoro algívoro, detritívoro insetívoro e insetívoro piscívoro. Variações na distribuição e diversidade do substrato de fundo foram importantes fatores influenciando a estrutura da comunidade nesses sistemas. Sendo assim, variações no tamanho dos igarapés mostraram reflexos nas comunidades de peixes.
\end{abstract}

Palavras-chave: Amazônia Central, comunidade de peixes, guildas tróficas.

\section{Introduction}

The variation in channel width is a key factor that influences the distribution of submerged branches, trunks and fine litter as well as the availability of light and the distribution of aquatic vegetation and fauna along the fluvial system (Cummins, 1974; Conners and Naiman, 1984; Walker, 1987). The canopy cover of streams has a strong influence on stream environment and is essential for maintaining water quality and species diversity (Walker, 1985, 1990; Bojsen and Barriga, 2002). The smaller the stream, the more dependent the biota is on leaf litter habitats

and allocthonous energy derived directly or indirectly from the forest (Minshall et al., 1983).

Studies of fish communities in temperate and tropical streams have shown that most species tend to occur in a restricted number of habitats (Zaret and Rand, 1971; Saul, 1975; Soares, 1979; Vianna, 1989; Rinne, 1992; Silva, 1993). Choosing a place to live depends on food availability, tolerance to physical or chemical factors, and predation intensity (Rinne, 1992). Caramaschi (1986) found that fish distribution in the small streams of the 
Tietê Basin were linked to physical characteristics of the channel and the heterogeneity of benthic substrates. The diversity and abundance of stream fish communities has also been associated with physical characteristics of the fluvial environment (Gorman and Karr, 1978; Moyle and Vondracek, 1985; Magalhães et al., 2002; Pouilly et al., 2006; Romanuk et al., 2006). In a study of a fish community of the Owego Creek, in New York, Sheldon (1968) concluded that variation in channel depth of stream habitats controlled the longitudinal distribution and diversity of fish assemblages.

Fish communities can be described in terms of their trophic structure and habitat associations (Uieda, 1984; Caramaschi, 1986; Sabino and Castro, 1990; Bojsen and Barriga, 2002; Pouilly et al., 2006). Fish diversity has been connected with habitat complexity in studies of the Central Amazon (Araújo-Lima et al., 1998). Trophic guilds are population groupings with the same feeding behaviour (Poff and Allan, 1995; Pouilly et al., 2006), and defined by both diet and feeding strategy (Knöppel, 1970; Zaret and Rand, 1971; Gorman and Karr, 1978; Gatz, 1979; Bowen, 1984; Zaret, 1984; Lowe-McConnel, 1987; Silva, 1993; Arcifa and Meschiatti, 1993). The feeding habits of some fishes vary according to the habitat (Silva, 1993; Bojsen and Barriga, 2002). Many fish are associated with particular habitats and consume food items limited in distribution to these environments (Zaret and Rand, 1971). Studies on the structure of fish communities in headwater streams are relatively scarce from the Amazon region due to the inaccessibility of these systems. The fish communities in these environments tend to be highly diverse and endemic (Menezes, 1996) making their study critical to regional conservation planning. The objective of the present study was to investigate the influence of variation in the bottom substrate and physical-chemical characteristics of channels on the trophic structure of fish communities in the headwater streams of the Jaú River at the beginning of the flooding period.

\section{Site Characterisation}

The Jaú River is a blackwater tributary of the Negro River, located between Moura and Novo Airão cities in the Central Amazon. This river is $300 \mathrm{~km}$ long and drains $10,000 \mathrm{~km}^{2}$ of largely undisturbed lowland tropical forest growing on Tertiary sediments of fluvio-lacustrian origin (Sioli, 1984). The Jaú basin is completely enclosed in the Jaú National Park (FVA, IBAMA, 1998). The climate in the study region is humid tropical with temperatures varying between 22 and $33{ }^{\circ} \mathrm{C}$ and annual rainfall varying between 1700 and $2500 \mathrm{~mm}$. Rainfall is seasonal with a distinct rainy period extending from November to June and a dry period extending from July through October. Rainfall is the heaviest in March, with an average of $350 \mathrm{~mm}$, and the lightest in November, with an average of $140 \mathrm{~mm}$ (FVA, IBAMA, 1998). Thirty-four headwater streams of the Jaú River were sampled in the present study (Figure 1). Most were acid black water streams with high concentrations of humic and fulvic acids derived from

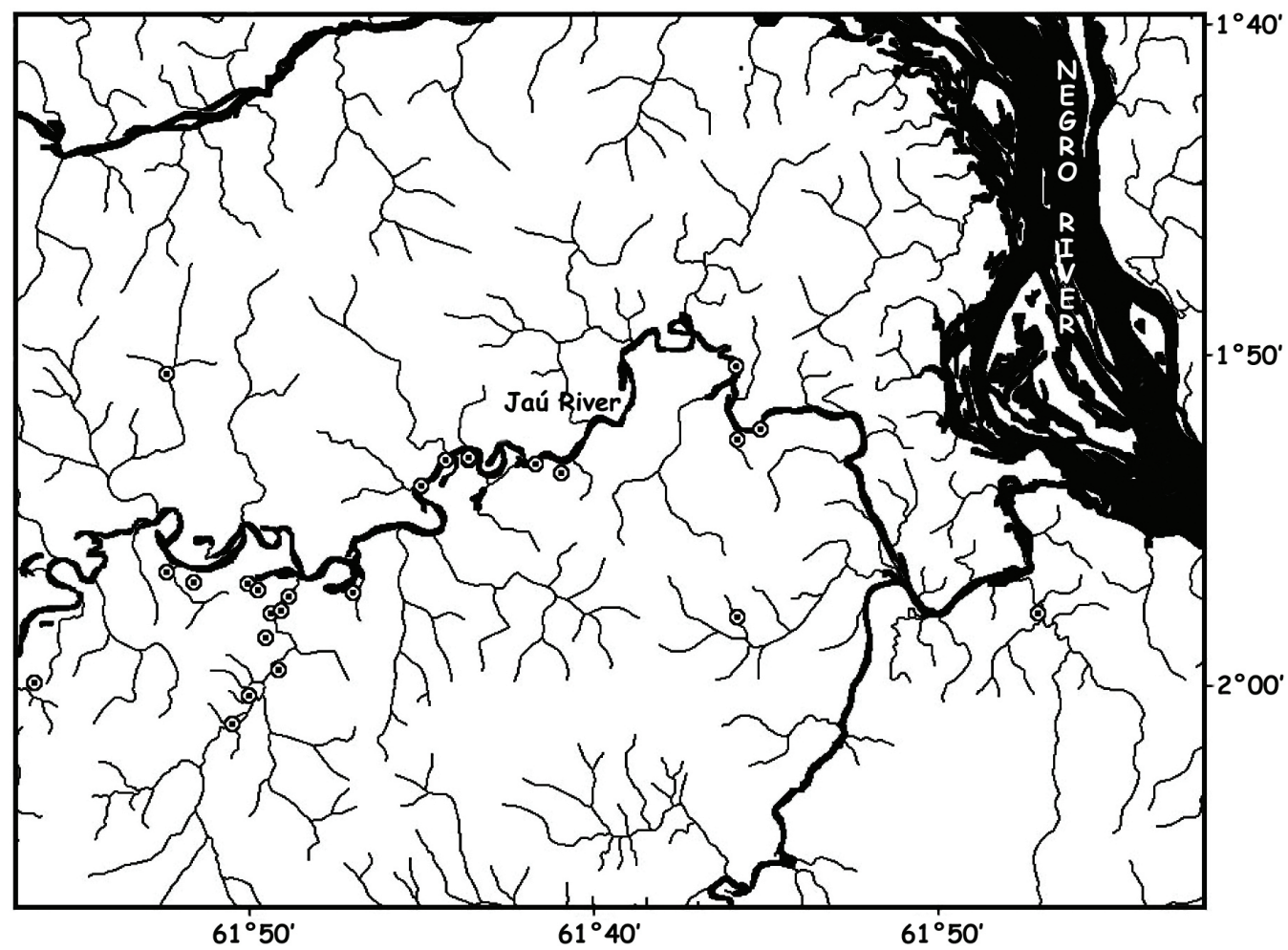

Figure 1. Location of 34 studied streams in Jaú River, Central Amazonian. 
sandy hydromorphic podsols (Marien, 1995). However, there were also a small number of less acid clear water streams, which drained predominantly lateritic soils and had much lower concentrations of organic acids (Leenheer, 1980). The $\mathrm{pH}$ of the study streams varied from 3 to 5.5 , water temperature varied between 23 and $26^{\circ} \mathrm{C}$, channel width ranged between 0.3 and 8.0 metres and channel depth varied from 0.3 to 1.7 metres.

\section{Material and methods}

Samples were collected from streams between November 1 and December 31 of 1998. All streams were sampled along a reach containing two complete meanders to guarantee that most stream habitats would be well represented. Water quality parameters (dissolved oxygen (DO), temperature, $\mathrm{pH}$ and conductivity) were determined at a central point along the sample reach. DO concentrations and temperature were determined with a Yellow Springs Instrument model 58 polarographic oxygen probe/thermister. Conductivity was estimated with VWR portable conductivity meter (model 2052), and $\mathrm{pH}$ was determined with an Orion model $510 \mathrm{pH}$ meter equipped with a Ross type probe for low ionic strength waters. Channel width was measured along ten equidistant lateral transects with the aid of a measuring line. Stream depth and bottom substrate were also determined at $10 \mathrm{~cm}$ intervals across each transect. Bottom substrates were classified in six categories: leaves, sand, trunks, mud, roots and rocks. Data on bottom substrates from all transects were used to estimate the average percentage of each substrate cover and habitat diversity for each reach. Habitat diversity and fish diversity were calculated using the Shannon and Weaver diversity index (1949).

Both hand dip nets and traps were cylindrical with a conical entrance fabricated from two liter PET bottles and were used to collect fish. Twelve fish traps, baited with meat or prey fish, were distributed randomly along each sampling reach and exposed for 24 hours. After removing the traps, 30 random samples were collected along the same reach with a dip net. A simple aggregated sample, including fishes from all traps and nettings was obtained for each stream and stored in $100 \mathrm{ml}$ glass jars in 70\% alcohol. Fish were anesthetised with dissolved ether before being killed in order to reduce suffering.

In the laboratory, the gut content of up to 20 adult individuals of each species was examined under a stereo microscope and classified into one of the following trophic guilds based on stomach content analyses (biovolume). The biovolume method was used adapted from Esteves and Galetti Junior (1995). The percentage of dominant food $(\% \mathrm{DF})$ was calculated considering the occupied area using a milimetric dish. The trophic- guild determination was based on the dominant food (more than $60 \%$ of disk area). Allocthonous insectivore (fish which eat terrestrial insects falling from riparian vegetation), autochthonous insectivore (fishes which eat insects which live in the stream), general insectivore (fishes which eat both aquatic and terrestrial insects), piscivore (fishes which eat exclusively fish), detritivorous planktivore (fishes which eat algae, bacteria, fungi and detrital organic matter), detritivorous insectivore (fishes which eat algae, bacteria, fungi, detrital organic matter and terrestrial and aquatic insects) and insectivorous piscivores (fishes which eat terrestrial and aquatic insects and fish). The fish community was directly observed while snorkelling (in the streams where depth allowed). Observation sessions lasted 15 minutes each, totalling approximately 2 hours of underwater observation per stream. During dives, visual census was used to help to determine spatial distribution and feeding behaviour.

Physical, chemical and substrate variables were aggregated into orthogonal axes using Multidimensional Scaling, in order to identify the most important parameters contributing to environmental variation. The influence of these environmental variations on guild abundance and fish species diversity were then investigated through Simple Linear Regression (Sneath and Sokal, 1973).

\section{Results}

Fish were collected in 34 streams and the most numerically abundant family was Characidae with 568 individuals in one stream. The least representative families with only one capture each were Electrophoridae, Nandidae and Ctenoluciidae (Table 1). Seven trophic guilds of stream fishes were identified: allocthonous insectivore, autochthonous insectivore, general insectivore, piscivore, detritivorous planktivore, detritivorous insectivore and insectivore piscivore. Allochthonous insectivore was the largest group in number, represented by the families: Characidae, Lebiasinidae and Gasteropelecidae. The largest biomass was found for general insectivore, represented by the families: Cetopsidae, Erythrinidae and Cichlidae. The autochthonous insectivore included the Characidiidae, Eleotrididae, Rivulidae, Trichomycteridae, Polycentridae, Curimatidae and the Gymnotiforms (Sternopygidae, Hypopomidae and Gymnotidae). The family Erythrinidae was the principle representative of the insectivorous piscivore. Piscivore were only encountered in ten streams and included the families: Synbranchidae, Characidae, Electrophoridae, Ctenoluciidae and Nandidae. The families Crenuchidae, Callichthyidae, Scoloplacidae and Pimelodidae represented the detritivorous insectivore. Detritivorous planktivore was the second largest group numerically and included the families Cichlidae, Doradidae and Auchenipteridae (Table 2).

The degree of co-variation among independent variables was investigated initially using correlation matrices. For the eight physical-chemical variables utilised ( $\mathrm{pH}$, conductivity, water temperature, volume of the stretch, depth and width of the stream, water flux, dissolved oxygen) we obtained 15 significant correlations, indicating a high degree of covariation among them (Table 3 ). All the physical variables of the canal presented significant correlation with dissolved oxygen, with the exception of $\mathrm{pH}$. We also found four significant correlations among bottom substrate types 
Table 1. The trophic guilds (TG, according to the acronyms in the TABLE 2) of fish species organised by families with the number of individuals $(\mathrm{n})$ of each species collected and the number of individuals used $(\mathrm{N})$ in order to determine the percentage of the dominant food (\% DF).

\begin{tabular}{|c|c|c|c|c|c|c|}
\hline Family & Species & & $\mathbf{n}$ & $\mathbf{N}$ & TG & $\% \mathrm{DF}$ \\
\hline Auchenipteridae & Trachelyichthys cf. decaradiatus (Mees, 1974) & 2 & 2 & $\mathrm{DP}$ & 80 & \\
\hline Callichthyidae & Megalechis thoracata (Valenciennes, 1840) & & 4 & 4 & DI & 100 \\
\hline Cetopsidae & Helogenes marmoratus (Günther, 1863) & & 5 & 5 & GI & 100 \\
\hline \multirow[t]{21}{*}{ Characidae } & Hemmigramus cf. analis 1 (Durbin, 1909) & & 322 & 20 & $\mathrm{AL}$ & 70 \\
\hline & Hemmigramus cf. bellottii (Steindachner, 1882) & & 413 & 20 & $\mathrm{AL}$ & 80 \\
\hline & Hemmigramus cf. ocellifer 1 (Steindachner, 1882) & & 16 & 20 & $\mathrm{AL}$ & 70 \\
\hline & Hemmigramus cf. vorderwinkleri 1 (Géry, 1963) & & 4 & 4 & $\mathrm{AL}$ & 85 \\
\hline & Hemmigramus gr. analis 2 & & 212 & 20 & $\mathrm{AL}$ & 80 \\
\hline & Hemmigramus aff. iota 1 (Durbin, 1909 ) & & 211 & 20 & $\mathrm{AL}$ & 75 \\
\hline & Hemmigramus aff. iota 2 & & 241 & 20 & $\mathrm{AL}$ & 85 \\
\hline & Hemmigramus aff. analis 3 & & 348 & 20 & $\mathrm{AL}$ & 80 \\
\hline & Hemmigramus aff. vorderwinkleri 2 & & 118 & 20 & $\mathrm{AL}$ & 80 \\
\hline & Hemmigramus aff. ocellifer 2 & & 44 & 20 & $\mathrm{AL}$ & 100 \\
\hline & Hemmigramus cf. schmardae 1 (Steindachner, 1882) & & 582 & 20 & $\mathrm{AL}$ & 85 \\
\hline & Hemmigramus aff. schmardae 2 & & 234 & 20 & $\mathrm{AL}$ & 75 \\
\hline & Moenkhausia cf. collettii (Steindachner, 1882) & & 18 & 18 & $\mathrm{AL}$ & 70 \\
\hline & Moenkhausia cf. cotinho (Eigenmann, 1908) & & 136 & 20 & $\mathrm{AL}$ & 75 \\
\hline & Moenkhausia cf. lepidura (Kner, 1858 ) & & 10 & 10 & $\mathrm{AL}$ & 75 \\
\hline & Iguanodectes cf. geisleri (Géry, 1970) & & 62 & 20 & $\mathrm{AL}$ & 80 \\
\hline & Astyanax cf. anterior (Eigenmann, 1908) & & 5 & 5 & $\mathrm{AL}$ & 95 \\
\hline & Gnathocharax cf. steindachneri (Fowler, 1913) & & 43 & 20 & $\mathrm{AL}$ & 100 \\
\hline & Acestrorhynchus aff. grandoculis (Menezes \& Géry, 1983) & & 2 & 2 & $\mathrm{AL}$ & 75 \\
\hline & Acestrorhynchus sp. & & 1 & 1 & PI & 100 \\
\hline & Hyphessobrycon aff. melazonatus (Durbin, 1908) & & 423 & 20 & $\mathrm{AL}$ & 80 \\
\hline \multirow[t]{2}{*}{ Characidiidae } & Klausewitzia sp. & & 81 & 20 & $\mathrm{AU}$ & 80 \\
\hline & Microcharacidium cf. eleotrioides (Géry, 1960) & & 4 & 4 & AU & 90 \\
\hline \multirow[t]{7}{*}{ Cichlidae } & Apistogramma sp. & & 419 & 20 & $\mathrm{DP}$ & 100 \\
\hline & Crenicichla cf. notophthalma (Regan, 1913) & & 24 & 20 & GI & 100 \\
\hline & Crenicichla sp.1 & & 3 & 3 & GI & 100 \\
\hline & Crenicichla sp.2 & & 4 & 4 & GI & 100 \\
\hline & Aequidens sp. & & 15 & 15 & $\mathrm{DP}$ & 100 \\
\hline & Heros severus (Heckel, 1840) & & 2 & 2 & $\mathrm{DP}$ & 100 \\
\hline & Cichlasoma sp. & & 3 & 3 & $\mathrm{DP}$ & 100 \\
\hline \multirow[t]{2}{*}{ Crenuchidae } & Crenuchus sp. & & 200 & 20 & DI & 100 \\
\hline & Poecilocharax weitzmani (Géry, 1965) & & 82 & 20 & DI & 100 \\
\hline Ctenoluciidae & Boulengerella lateristriga (Boulenger, 1895) & & 1 & 1 & PI & 100 \\
\hline Curimatidae & Curimatopsis evelynae ( Géry, 1964) & & 10 & 10 & $\mathrm{AL}$ & 90 \\
\hline \multirow[t]{3}{*}{ Doradidae } & Physopyxis cf. lira (Cope, 1871) & & 3 & 3 & $\mathrm{DP}$ & 100 \\
\hline & Acanthodoras sp. & & 1 & 1 & $\mathrm{DP}$ & 100 \\
\hline & $\begin{array}{l}\text { Acanthodoras cf. spinosissimus (Eigenmann \& Eigenmann, } \\
\text { 1888) }\end{array}$ & & 9 & 9 & $\mathrm{DP}$ & 100 \\
\hline Electrophoridae & Electrophorus electricus (Linnaeus, 1766) & & 1 & 1 & PI & 100 \\
\hline \multirow[t]{2}{*}{ Eleotrididae } & Microphilypnus sp.1 & & 66 & 20 & AU & 90 \\
\hline & Microphilypnus sp. 2 & & 11 & 11 & $\mathrm{AU}$ & 85 \\
\hline \multirow[t]{3}{*}{ Erythrinidae } & Erythrinus erythrinus (Bloch \& Schneider, 1801) & & 52 & 20 & GI & 100 \\
\hline & Hoplias cf. malabaricus (Bloch, 1794) & & 25 & 20 & IP & 90 \\
\hline & Hoplias cf. lacerdae (Miranda Ribeiro, 1908) & & 10 & 10 & IP & 95 \\
\hline Gasteropelecidae & Carnegiella strigata (Günther, 1864) & & 6 & 6 & $\mathrm{AL}$ & 90 \\
\hline \multirow[t]{5}{*}{ Lebiasinidae } & Pyrrhulina cf. laeta (Cope, 1872) & & 49 & 20 & $\mathrm{AL}$ & 90 \\
\hline & Copella cf. nattereri (Steindachner, 1876) & & 529 & 20 & $\mathrm{AL}$ & 85 \\
\hline & Copella nigrofasciata (Meinken, 1952) & & 474 & 20 & $\mathrm{AL}$ & 90 \\
\hline & Nannostomus marginatus (Eigenmann, 1909) & & 15 & 15 & $\mathrm{AL}$ & 80 \\
\hline & Nannostomus eques (Steindachner, 1876) & & 26 & 20 & $\mathrm{AL}$ & 85 \\
\hline
\end{tabular}


Table 1. Continued...

\begin{tabular}{llcccc}
\hline \multicolumn{1}{c}{ Family } & \multicolumn{1}{c}{ Species } & n & N & TG & \% DF \\
\hline Pimelodidae & Nemuroglanis lanceolatus (Eigenmann \& Eigenmann, 1889) & 20 & 20 & DI & 100 \\
Polycentridae & Monocirrhus polyacanthus (Heckel, 1840) & 1 & 1 & AU & 90 \\
Rivulidae & Rivulus cf. ornatus (Garman, 1895) & 23 & 20 & AU & 85 \\
& Rivulus cf. compressus (Henn, 1916) & 1 & 1 & AU & 80 \\
Scoloplacidae & Scoloplax cf. dolicholophia (Schaefer, Weitzman \& Britski, & 1 & 1 & DI & 100 \\
& 1989) & & & & \\
Synbranchidae & Synbranchus sp. & 16 & 16 & PI & 100 \\
Trichomycteridae & Tricomycterus sp. & 3 & 3 & PI & 100 \\
Hypopomidae & Hypopygus cf. lepturus 1 (Hoedeman, 1962) & 19 & 19 & AU & 70 \\
Gymnotidae & Hypopygus aff. lepturus 2 & 55 & 20 & AU & 65 \\
Sternopygidae & Microsternarchus bilineatus (Fernández-Yépez, 1968) & 1 & 1 & AU & 70 \\
& Stegostenopos criptogenes (Steindachner, 1880) & 1 & 1 & AU & 75 \\
& Gymnotus anguillaris (Hoedeman, 1962) & 10 & 10 & AU & 85 \\
& Gymnotus cf. pedanopterus (Mago-Leccia, 1994) & 2 & 2 & AU & 85 \\
& Sternopygus macrurus (Bloch \& Schneider, 1801) & 1 & 1 & AU & 75 \\
\hline
\end{tabular}

Table 2. Abundance of individuals, biomass (g), species richness and family richness of trophic guilds encountered in this study.

\begin{tabular}{lcccc}
\hline \multicolumn{1}{c}{ Trophic - Guild } & Individuals & Biomass & Species & Families \\
\hline Allocthonous insectivore (AL) & 4553 & 1127 & 27 & 4 \\
Autochthonous insectivore (AU) & 276 & 50 & 14 & 7 \\
General insectivore (GI) & 88 & 1489 & 5 & 3 \\
Piscivore (PI) & 22 & 1371 & 5 & 5 \\
Detritivorous planktivore (DP) & 454 & 250 & 8 & 3 \\
Detritivorous insectivore (DI) & 307 & 247 & 5 & 4 \\
Insectivorous piscivore (IP) & 35 & 596 & 2 & 1 \\
Total & 5735 & 5130 & 66 & \\
\hline
\end{tabular}

Table 3. Pearson and Kendall product-moment correlations between the 16 independent variables in two significant MDS ordination axes (DO; air temperature, water temperature; water flux; Conductivity; $\mathrm{pH}$; size of reach; width; depth; and bottom coverage of the habitats: Sand $\%$, Root $\%$, Mud \%, Trunk \%, Rock \% and Leaf \%

\begin{tabular}{lcc}
\hline & Axe 1 & Axe 2 \\
\cline { 2 - 3 } & $\mathbf{R}$ & $\mathbf{R}$ \\
\hline DO & -0.311 & 0.236 \\
air temperature & 0.140 & 0.109 \\
water temperature & 0.235 & 0.063 \\
water flux & -0.473 & 0.121 \\
Conductivity & 0.062 & -0.111 \\
pH & 0.016 & 0.117 \\
Width & $-0.914^{*}$ & -0.038 \\
Depth & $-0.919^{*}$ & 0.092 \\
Sand \% & $-0.636^{*}$ & $0.803^{*}$ \\
Root \% & -0.024 & 0.011 \\
Mud \% & 0.353 & 0.185 \\
Trunk \% & 0.197 & 0.381 \\
Rock \% & -0.320 & 0.072 \\
Leaf \% & $0.552^{*}$ & $-0.859^{*}$ \\
\hline
\end{tabular}

(*significant variables). (leaf + sand, leaf + rock, rock + trunk and mud + trunk $).$ Analysing all independent variables together, we encountered 34 significant correlations, including interactions between the substratum and channel morphology. To reduce the degree of co-variation among independent variables and the degrees of freedom of the final statistical analyses, ordinal orthogonal axes were derived from 14 original independent variables. Two axes explained the majority of the environmental variations encountered in these streams. Axis one was strongly correlated with channel morphology and dissolved oxygen. It was also significantly influenced by two benthic substrate components (percentage of leaf and sand cover). This axis represented the systematic change in morphology canal and habitats. Axis two, in turn, was highly influenced by two bottom substrate components, sand and leaf cover, which contributed positively and negatively to the axis, respectively. This axis represented the variation in bottom substrates, independent of stream size. Only four parameters were significantly correlated with these two orthogonal axes (channel depth, channel width, and sand and leaf cover), they were used as independent variables in subsequent linear regression analyses with abundance of fish guilds. 
The biomass of allocthonous insectivore increased in channels with a higher percentage of sandy bottom substrate (Figure 2a). Detritivorous insectivore biomass, in contrast, increased significantly in channels with a higher percentage of leaf substrate (Figure 2b). General insectivores tended to increase in streams with higher proportions of leafy substrate too (Figure 2c). The abundance of allocthonous insectivore increased significantly with both channel width and depth (Figuress 3a, 3b, 3e, and 3f). The number of piscivorous and the biomass of autochthonous insectivore also increased with depth (Figures $3 \mathrm{c}$ and $3 \mathrm{~d}$ ). Significant relationships were found between benthic habitat diversity and fish diversity (Figure 4a), general insectivore's biomass (Figure 4b), autochthonous insectivore number (Figure 4c), and detritivorous insectivore biomass (Figure 4d).

\section{Discussion and Conclusion}

The physical characteristics vary systematically along the stream size, and this gradient results in a continuum biotic adjustment which was predicted by the River Continuum Concept (Vannote et al., 1980). The physical characteristics of each stream including current speed, channel width and depth, log dam size and frequency and meander size were combined to create a complex mosaic of habitats which influence the trophic structure, diversity and composition in aquatic invertebrate communities (Cargnin-Ferreira and Forsberg, 2000).Also many of these physical characteristics make predictions about the headwater stream's ichthyofauna (Magalhães et al., 2002; Pouilly et al., 2005; Romanuk et al., 2006). In this study, the distributions of fish guilds were influenced by local variations in the presence, abundance and diversity of bottom substrates.

According to Vannote et al. (1980), as stream size increases, the reduced importance of terrestrial organic input coincides with significant enhancement of autochthonous primary production and organic transport from upstream. Leaf and sand bottom substrates were identified as the most important habitats in this study. The frequent association of certain trophic guilds with these substrates demonstrates its importance to fish communities of the headwaters. These habitats were found to have differing quantities and when one was abundant the other one was scarce. This was in agreement with Vannote et al. (1980): the first order systems showed an abundance of leaves and fine detritus, which decreased with the increasing size of the channel.

Detritivorous insectivore were found in leafy substratum, which contained fine detritus, fungi and a rich invertebrate fauna, that served as the predominant food base for this group. However, the sandy bottom substrates preferred by allocthonous insectivores offer few refuges for insect prey, which presumably facilitates their visualisation, and capture both at the surface and the bottom of the water column (Flecker and David Allan, 1984); there appears to be some disagreement with this concept, because the larger the size of the channel the lower the significance of allochthonous items. General insectivores used a passive
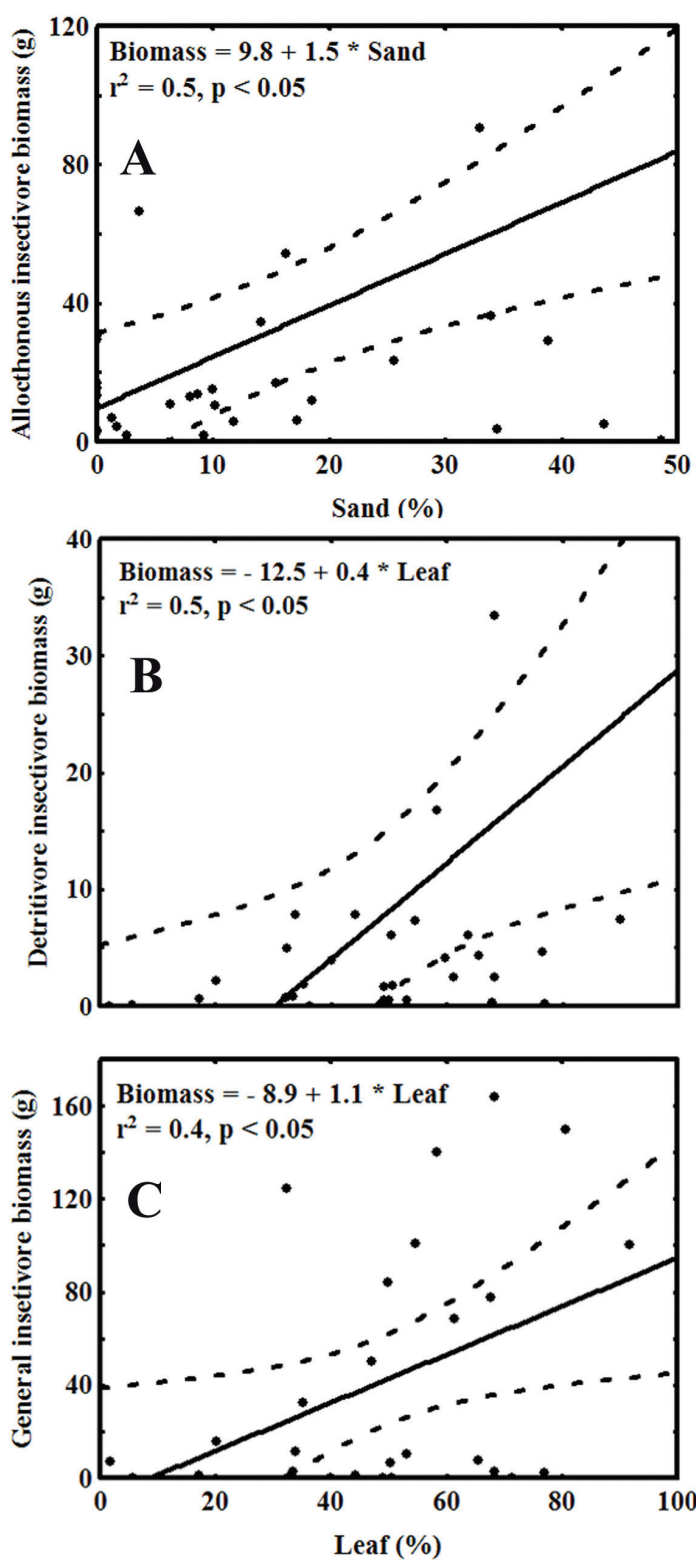

Figure 2. Relationship between $\%$ benthic sand cover and A) allocthonous insectivore biomass, and relationship between $\%$ benthic leaf cover and B) detritivore insectivore biomass, and C) general insectivore biomass.

"sit and wait" strategy, camouflaging themselves among the leaves and the bottom detritus while waiting for prey (A. Kemenes, personal observation). This sedentary cryptic behaviour explains its preference for leafy substratum and small headwater streams. The positive association encountered between piscivore numbers and stream size could be linked to the large body size of many piscivores that deterred them from gaining access to the smaller streams.

One of the principal hunting strategies adopted by the allochthonous insectivores was to diminish their mobility and maintain a homogenous spatial distribution in order 

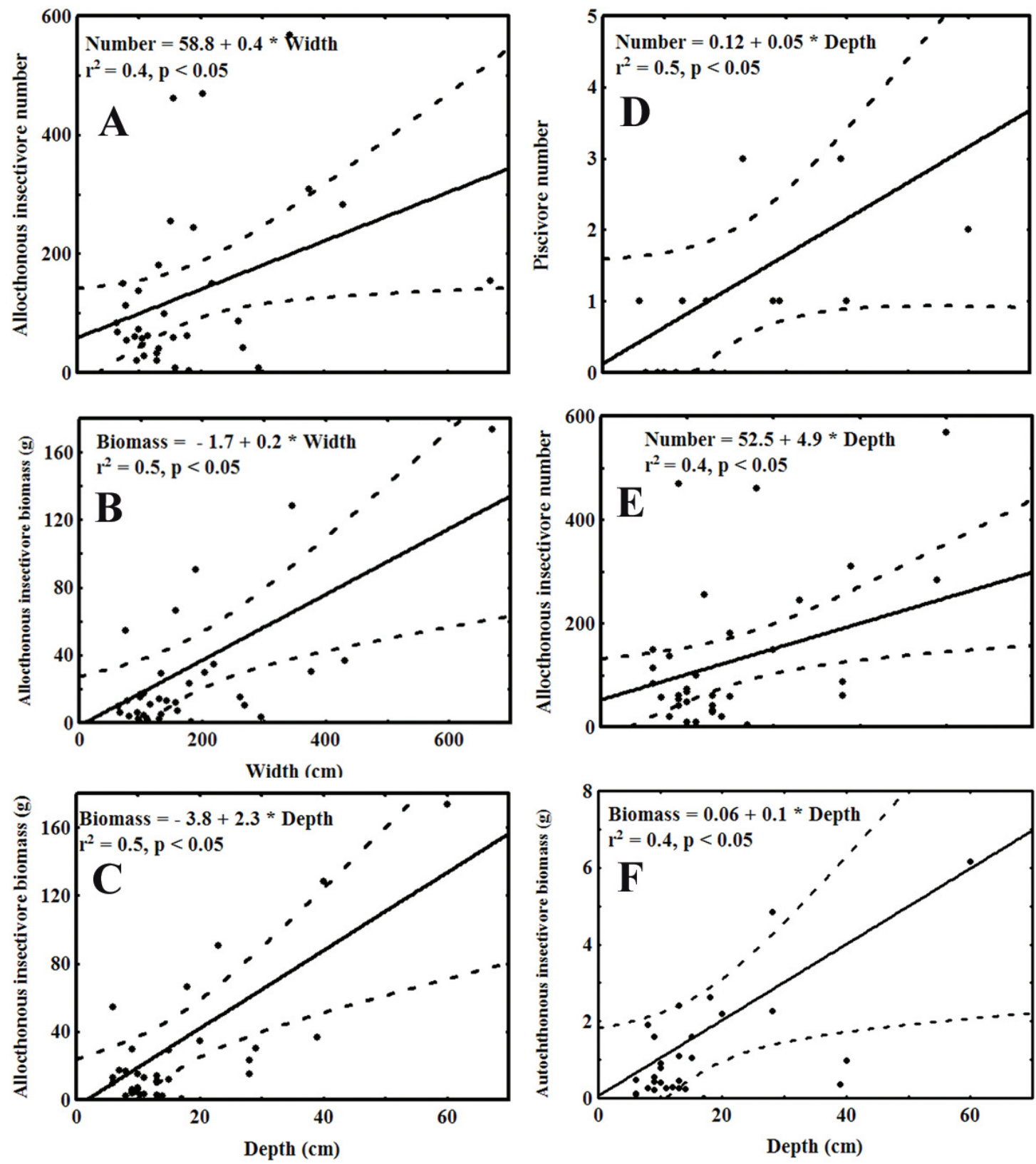

Figure 3. Relationship between channel width and allocthonous insectivore abundance A) individual number and B) biomass; relationship between channel depth and C) autochthonous insectivore biomass, D) piscivore number, and allocthonous insectivore abundance E) individual number and F) biomass.

to cover as much space as possible while waiting for insects to fall from the forest. In contrast, autochthonous insectivores actively looked for their prey and tended to expand their search territory to its maximum extent. Both strategies were most successful in wider and deeper canals where it was easy to establish energy efficient circular territories and both guilds, in consequence, tended to prefer this physical characteristic. This explains why the allochthonous insectivores prefer medium headwaters streams with sandy bottom coverage, in disagreement with Vannote et al. (1980). These two groups used these overlapping territories during the same period of the day but with a different spatial focus, maybe, to avoid competition, or possibly, due to the location of preferential food. The allocthonous insectivores foraged near the surface while the autochthonous insectivores fed along the bottoms and sides of the channels (A. Kemenes, personal observation).

The distributions of most fish though did not appear to be linked to a specific habitat, but to the mixture of habitats encountered in a location. The diversity of bottom substrates 

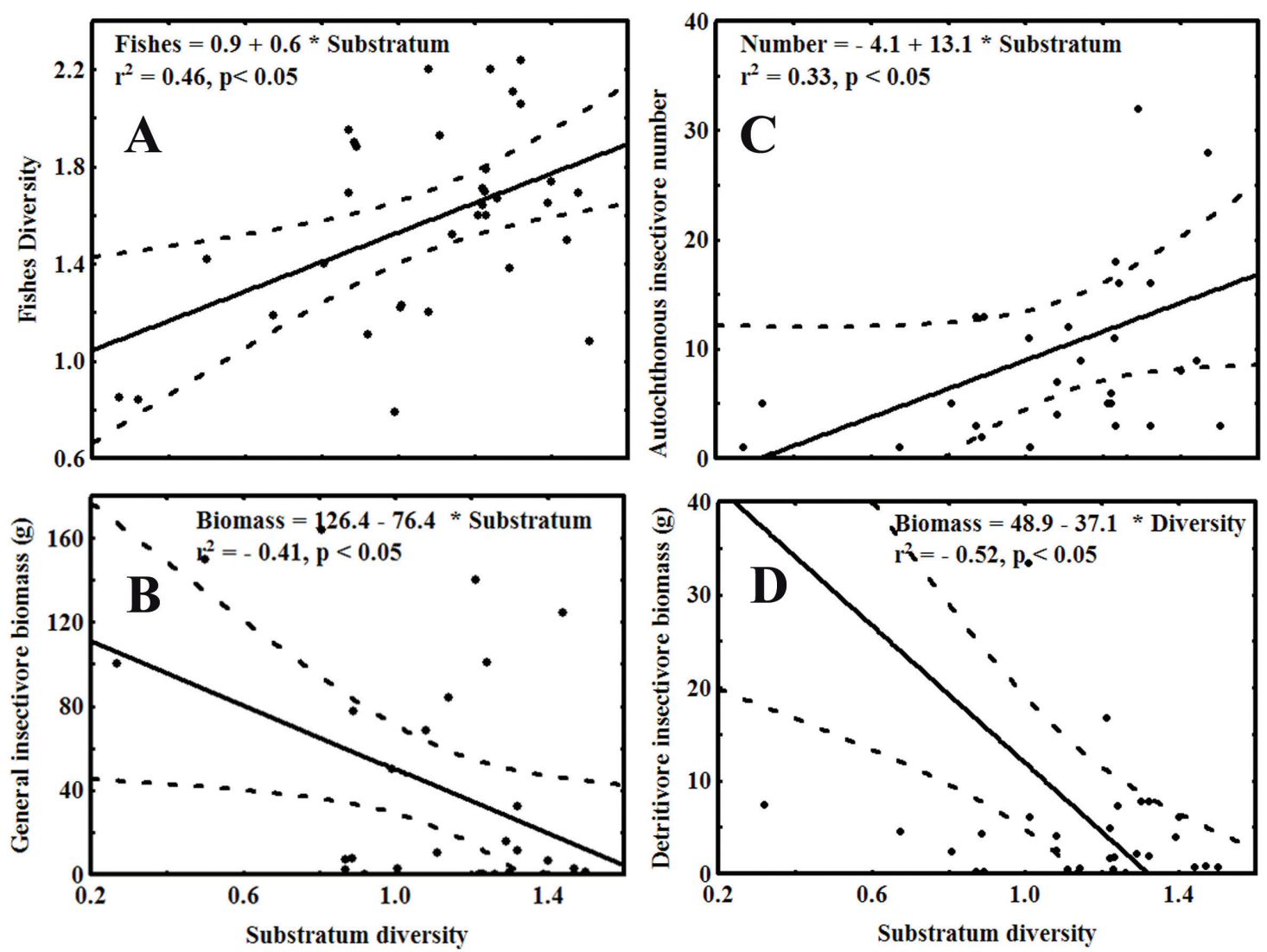

Figure 4. Relationship between benthic substrate diversity and A) fish species diversity, B) general insectivore biomass, C) autochthonous insectivore numbers, and D) detritivore insectivore biomass.

appeared to be a key factor in these headwater streams. The greatest diversity of ichthyofauna was encountered in channels with the highest substrate diversity, which offered the greatest variety of food resources, living conditions and refuges for the existing fish community. These results corroborate the relationships between fishes diversity and habitat complexity found in other studies of Central Amazonia (Araújo-Lima et al., 1998), French Guiana (Merigoux et al., 1998) and in North America (Gorman and Karr, 1978). The significant correlations encountered between habitat diversity and the biomass of general insectivores, number of autochthonous insectivores, and detritivorous insectivore biomass indicated that environmental character might also determine the abundance of specific groups.

The River Continuum Concept may explain the distributions of aquatic invertebrates (Cargnin-Ferreira and Forsberg, 2000) and fishes in tropical and temperate zone stream channels (Magalhães et al., 2002; Pouilly et al., 2005; Romanuk et al., 2006). In this study, the stream size, the variability of benthic substrates and the diversity of these habitats had influence on the trophic structure and diversity of stream fish communities. The aquatic structure is essential for the headwater fish communities. This result has important implications for the increase of ichthyofauna knowledge in tropical fluvial ecosystems.

\section{Acknowledgements}

This study was made possible with support from the Environmental Brazilian Institute (IBAMA-AM), the National Research Institute of the Amazon (INPA/CPEC), the Amazon Victoria Foundation (FVA) and the O Boticário Fundation. For the aid, we wish to especially thank Dr. Eduardo Martins Venticinque, Dr. Jansen Zuanon, Dra. Ilse Walker, Dr. Willian Magnunsun, Dr. Willian Laurance, Dr. Carlos Araújo-Lima; and Mr. José Palheta.

\section{References}

ARAÚJO LIMA, CARM., JIMÉNEZ, LF., OLIVEIRA, RS., ETEROVICK, PC., MENDOZA, U. and JEROZOLIMNKI, A., 1998. Relação entre o número de espécies de peixes, complexidade do habitat e ordem do riacho nas cabeceiras de um tributário do rio Urubu, Amazônia Central. Acta Limnologica Brasiliensia, vol. 11, p. 127-135.

ARCIFA, MS. and MESCHIATTI, AJ., 1993. Distribution and feeding ecology of fishes in a Brazilian reservoir: Lake Monte Alegre. Interciencia, vol. 18, p. 302-313.

BOJSEN, BH. and BARRIGA, R., 2002. Effects of deforestation on fish community structure in Ecuadorian Amazon streams. Freshwater Biology, vol. 47, no. 11, p. 2246-2260. http://dx.doi. org/10.1046/j.1365-2427.2002.00956.x. 
BOWEN, SH., 1984. Detritivory in Neotropical fish communities. In ZARET, TM. (Ed.). Evolutionary ecology of Neotropical freshwater fishes. Netherlands: Dr. W. Junk Publishers. 234 p.

CARAMASCHI, EP., 1986. Distribuição da ictiofauna de riachos das bacias do Tietê e do Paranapanema, junto ao divisor de águas (Botucatu, SP). São Carlos: Departamento de Ciências Biológicas, Universidade Federal de São Carlos. 245 p. Tese de doutorado.

CARGNIN-FERREIRA, E. and FORSBERG, BF., 2000. Trophic structure of macroinvertebrate communities in the Jaú River System (Central Amazon, Brazil). Brazilian Journal of Ecology, vol. 3 , p. 59-66.

CONNERS, ME. and NAIMAN, R., 1984. Particulate allocthonous inputs: relationships with stream size in an undisturbed watershed. Canadian Journal of Fisheries and Aquatic Sciences, vol. 41, no. 10, p. 1473-1484. http://dx.doi.org/10.1139/f84-181.

CUMMINS, KW., 1974. Structure and function of stream ecosystems. Bioscience, vol. 24, no. 11, p. 631-641. http://dx.doi. org/10.2307/1296676.

ESTEVES, KE. and GALETTI JUNIOR, PM., 1995. Food partitioning among some characids of a small Brazilian floodplain lake from the Paraná River basin. Environmental Biology of Fishes, vol. 42, no. 4, p. 375-389. http://dx.doi.org/10.1007/BF00001468.

FLECKER, AS. and DAVID ALLAN, J., 1984. The importance of predation, substrate and spatial refugia in determining lotic insect distributions. Oecologia, vol. 64, no. 3, p. 306-313. http:// dx.doi.org/10.1007/BF00379126.

Fundação Vitória Amazônica - FVA; Instituto Brasileiro do Meio Ambiente e dos Recursos Naturais Renováveis - IBAMA 1998. Plano de Manejo do Parque Nacional do Jaú. Manaus. 146 p.

GATZ JUNIOR, AJ., 1979. Community organization as indicated by morphological features. Ecology, vol. 60, no. 4, p. 711-718. http://dx.doi.org/10.2307/1936608.

GORMAN, OT. and KARR, JR., 1978. Habitat structure and stream fish communities. Ecology, vol. 59, no. 3, p. 507-515. http://dx.doi.org/10.2307/1936581.

KNÖPPEL, H-A., 1970. Food of central Amazonian fishes, contribution to the nutrient ecology of Amazonian rain-foreststreams. Amazoniana, vol. II, p. 257-352.

LEENHEER, JA., 1980. Origin and nature of humid substances in the waters of the Amazon River basin. Acta Amazonica, vol. 10 , p. 513-526.

LOWE-MCCONNEL, RH., 1987. Ecological studies in tropical fish communities. Cambridge: Cambridge University Press. 382 p.

MAGALHÃES, MF., BATALHA, DC. and COLLARESPEREIRA, MJ., 2002. Gradients in stream fish assemblages across a Mediterranean landscape: contributions of environmental factors and spatial structure. Freshwater Biology, vol. 47, no. 5, p. 1015-1031. http://dx.doi.org/10.1046/j.1365-2427.2002.00830.x.

MARIEN, JAS., 1995. Comunidades de camarões em duas reservas da Amazônia Central: Parque Nacional do Jaú e Estação Ecológica de Mamirauá. Manaus: INPA/UA, 84 p. Tese de Doutorado.

MENEZES, NA., 1996. Methods for assessing fresh water fish diversity. In BICUDO, CEM. and MENEZES, NA. Biodiversity in Brazil: a first approach. São Paulo: CNPq. p. 289-295.

MÉRIGOUX, S., PONTON, D. and MÉRONA, B., 1998. Fish richness and species-habitat relationships in two coastal streams of French Guiana, South America. Environmental Biology of Fishes, vol. 51, no. 1, p. 25-39. http://dx.doi.org/10.1023/A:1007422100976.
MINSHALL, GW., PETERSEN, RC., CUMMINS, KW., BOTT, TL., SEDELL, JR., CUSHING, CE. and VANNOTE, RL., 1983. Interbiome comparison of stream ecosystem dynamics. Ecological Monographs, vol. 53, no. 1, p. 1-25. http://dx.doi. org/10.2307/1942585.

MOYLE, PB. and VONDRACEK, B., 1985. Persistence and structure of the fish assemblage in a small California stream. Ecology, vol. 66, no. 1, p. 1-13. http://dx.doi.org/10.2307/1941301.

POFF, NL. and ALLAN, JD., 1995. Functional organization of stream fish assemblages in relation to hydrological variability. Ecology, vol. 76, no. 2, p. 606-627. http://dx.doi.org/10.2307/1941217.

POUILLY, M., BARRERA, S. and ROSALES, C., 2006. Changes of taxonomic and trophic structure of fish assemblages along an environmental gradient in the Upper Beni watershed (Bolivia). Journal of Fish Biology, vol. 68, no. 1, p. 137-156. http://dx.doi. org/10.1111/j.0022-1112.2006.00883.x.

RINNE, JN., 1992. Physical habitat utilization of fish in a Sonoran Desert stream, Arizona, southern United States. Ecology Freshwater Fish, vol. 1, no. 1, p. 35-41. http://dx.doi. org/10.1111/j.1600-0633.1992.tb00005.x.

ROMANUK, TN., JACKSON, LJ., POST, JR., MCCAULEY, E. and MARTINEZ, ND., 2006. The structure of food webs along river networks. Ecography, vol. 29, no. 1, p. 3-10. http://dx.doi. org/10.1111/j.2005.0906-7590.04181.x.

SABINO, J. and CASTRO, RMC., 1990. Alimentação, período de atividade e distribuição espacial dos peixes de um riacho da floresta atlântica (Sudeste do Brasil). Revista Brasileira de Biologia, vol. 50, p. 23-36.

SAUL, WG., 1975. An ecological study of fishes at a site in Upper Amazonian Ecuador. Proceedings. Academy of Natural Sciences of Philadelphia, vol. 127, p. 93-134.

SHANNON, CE. and WEAVER, L., 1949. The mathematical theory of communication. Urbana: Universidade de Illinois Press. 345 p.

SHELDON, A., 1968. Species diversity and longitudinal succession in stream fishes. Ecology, vol. 49, no. 2, p. 193-198. http://dx.doi. org/10.2307/1934447.

SILVA, CPD., 1993. Alimentação e distribuição espacial de algumas espécies de peixes no igarapé do Candirú, Amazonas, Brasil. Acta Amazonica, vol. 23, p. 271-285.

SIOLI, H., 1984, The Amazon and its main affluents: hydrograph, morphology of the river courses and river types. In SIOLI, H. (Ed.). The Amazon. Limnology and landscape ecology of a mighty tropical river and its basin. Dordrecht: Dr. Junk Publishers. p. 127-166.

SNEATH, PHA. and SOKAL, RR., 1973. Numerical Taxonomy. San Francisco: W.H. Freeman \& CO. 234 p.

SOARES, MGM., 1979. Aspectos ecológicos (alimentação e reprodução) dos peixes do igarapé do Porto. Aripuanã, MT. 84 p. Tese de Doutorado.

UIEDA, VS., 1984. Ocorrência e distribuição dos peixes em um riacho de água doce. Revista Brasileira de Biologia, vol. 44, p. 203-213.

VANNOTE, RL., MINSHALL, GW., CUMMINS, KW., SEDELL, JR. and CUSHING, CE., 1980. The River Continuum Concept. Canadian Journal of Fisheries and Aquatic Sciences, vol. 37, no. 1, p. 130-137. http://dx.doi.org/10.1139/f80-017.

VIANNA, JP., 1989. Estrutura de comunidade dos peixes do Ribeirão Santana ao longo de gradientes ambientais. São Paulo. 115 p. Tese de Doutorado. 
WALKER, I., 1985. On the structure and ecology of the microfauna in the Central Amazonian forest stream igarapé da Cachoeira. Hydrobiologia, vol. 122, no. 2, p. 137-152. http:// dx.doi.org/10.1007/BF00032100.

WALKER, I., 1987. The biology of streams as part of Amazonian forest ecology. Experientia, vol. 43, no. 3, p. 279-287. http:// dx.doi.org/10.1007/BF01945551.
WALKER, I., 1990. Ecologia e biologia dos igapós e igarapés. Ciência Hoje, vol. 11, p. 44-53.

ZARET, TM. and RAND, AS., 1971. Competition in tropical stream fishes: support for the competitive exclusion principle. Ecology, vol. 52, no. 2, p. 336-342. http://dx.doi.org/10.2307/1934593.

ZARET, TM.,1984. Evolutionary ecology of neotropical freshwater fishes. Netherlands: Dr. W. Junk Publishers. 230 p. 